\title{
THE SITUATION IN THE “MIDDLE EAST" AFTER THE DECLINE OF THE OTTOMAN EMPIRE: PROVIDING A THEORETICAL SOLUTION FOR THE INSTABILITY
}

Birkan ERTOY

\begin{abstract}
Instability in the Middle East is a well-known phenomenon and this condition is mostly seen as arising from the rivalry of great powers in the region. However, during the time of the Ottoman Empire, there was stability in the region until its decline. After the establishment of nation-states in the region, stability lasted for a while until international powers left. In this sense, what is needed for stability is a power that is able to unite the region states in an inclusivist manner as the Ottoman Empire had previously managed. Even though there is plenty of research about the region, there has been little analysis of the region using a theoretical framework. Additionally, there is no research that uses an Eastern approach since the dominant knowledge is produced by the West. Therefore, this article is an attempt to analyse instability in the region using a new geopolitical theory called Barakah Circles. Moreover, Turkey's role in the Middle East will be discussed in line with the theoretical perspective of this study.
\end{abstract}

KEYWORDS: Barakah Circles Theory, Arab World, Instability, Ottomans, Turkey, Inclusivist Policies.

\section{INTRODUCTION}

The term "Middle East"1 was first used by traditional geopolitician Alfred T. Mahan. Before his conceptualising, the term for referring to the East was 'Orient', meaning 'land of rising sun' in Latin. 'Occident' or 'land of setting sun' on the other hand, referred to the West (Stewart, 2009: 5). Even the meaning of these words is still the same in geopolitical terms - it seems that the sun does not rise from the East, but rather it sets in contemporary international relations. The reason behind this is very simple, as Edward Said argued: Orientalism (the study of the East) "has been an aspect of both imperialism and colonialism." (1979: 123). Even the term 'Middle East' was first used in the $19^{\text {th }}$ century to define the "midway to the British colonies in the East" (Ergul Jorgensen, 2019: 82).

To understand the current situation in the Middle East, it will be useful to first turn to Dona J. Stewart's words. She begins her discussion with these words: "Think of the Middle East. Quickly write down the first five words that come to mind". The author claims that violence and conflict are prominent among the

PhD Student, International Relations, Social Sciences University of Ankara (ASBU), Turkey, birkan.ertoy@gmail.com. 
answers (2009: 3). In short, most of us believe that the Middle East is "chronically unstable" as Alan Richards claims (1995: 175). Alas, it is true to a large extent. Even if we find a person randomly and ask what the Middle East is associated with, their answer will most likely be within Stewart's categories of answers. Even if it might be assumed that the Arab World had divided itself, there are certain foreign interferences contributing to the current situation as well. It is not surprising that after the colonial activities of major Western powers, the Middle East became a 'suitable ground' for violence. As Ayoob argues, "superpowers tolerate and quite often, encourage conflicts in the Third World [or in the Middle East in general]" to have testing grounds for the new weapon systems they produce (1983: 48). No less importantly, as Ergul Jorgensen argues, "domination over these lands has been a precondition for being a superpower" (2019: 86). In relation to the violence issue and the encouragement of conflicts, the Middle East has continued to sustain its instable condition.

It is a well-known fact that there are two regional and two international actors that might be considered as the main actors in the Middle East. On the other hand, there are other actors that try to be regional powers by becoming a part of the conflicts in the region ${ }^{2}$. While Turkey, Iran and Israel can be considered as regional actors, the USA and Russian Federation can be considered as the international actors in the region. Yet it is clear that there is not any established power that actually belongs to or has organic ties with the region in the Middle East, except Iran and Turkey in terms of historical ties and geopolitical proximity. Other actors' relation with the region is artificial, established by their power and some historical agreements such as the Sykes-Picot Agreement. Alongside the actors in the region, it is clear that there is no stability in the region and from a pessimistic point of view, there are no signs for change in the horizon. Commonly, the Middle East was referred to as a 'swamp', in which not a single state would want to be present in the region. However, in reality, major powers seem to 'enjoy' operating in this swamp. In this sense, another reason why 'instability' is the main feature of the Middle East is because of the power politics of opportunistic states in the region. From the perspective of this study, understanding and explaining the instability in the region can be be related to the lack of a regional power that has organic ties with the region.

The European Union, for instance, is a unique cooperation amongst its members that are considered equal in the government of the continental and their attitude towards world affairs. This equality is the key for peace and stability in EU. This is because cooperation is considered as the 'main thematic tool' to maintain stability in the region ("Peace and Stability", European Commission). In comparison, the Soviet Union was the supreme power in Eastern Europe during the Cold War, with the region being relatively stable due to its power as compared to Eastern European countries. But there has never been an equal union or regional power that holds states together in the Middle East since the decline of the Ottoman Empire. When the Ottomans were the only power in the region, 
there was stability, but when the establishment of the state of Israel was completed, this stability began to peter out. Moreover, when the Ottoman Empire lost its power over the Middle East, other international actors tried to replace the Empire. However, Ottoman and Western policy tools were very different. The Ottoman Empire utilised inclusive policies while Western policies were of an exclusive nature. In other words, the Empire endeavoured for harmony, while Western colonial policies used the establishment of nation-states in the Arab World for their own interests.

After the decline of the Ottoman Empire, none of the states that split up from the Empire have experienced a peaceful period or stability inside their boundaries or even in the 'Middle East' in general. This study argues that the reason for instability is the artificiality in the region. According to the Barakah Circle theory, which is a developing approach by Abd al-Fattah El-Awaisi, if there is chaos in Islamicjerusalem, other states will also be affected according to the ratio of their distance (2016: 53-54). Indeed, it is clear that former Ottoman lands that are close to Islamicjerusalem are being affected more, and further countries affected less. The very reason might be due to the conflict in Islamicjerusalem, or on the other hand, might be the absence of an established regional power that has historical and organic ties with region states.

This study, therefore, aims to argue that the reason for the instability in the region is the absence of a regional power that has organic ties with the region. In doing so, El-Awaisi's new geopolitical theory will be the framework of this study because of its uniqueness in understanding instability on a systemic level. Along with this aim, this study will attempt to provide an answer for the conflict in the region by using the inclusivist essence of the Barakah Circles theory. Lastly, the article is an attempt to test the nucleus of Abd as-Fattah El-Awaisi's theory for the Eastern theoretical development process.

\section{BARAKAH CIRCLES AS A NEW GEOPOLITICAL THEORY}

Abd al-Fattah El-Awaisi argues that Islamicjerusalem is the heart of the world and that Barakah or the 'divine gift' spreads to the world in circles. This is the reason why he named his new geopolitical theory as 'Barakah Circles'. In accordance with this new geopolitical approach, al-Aqsa Mosque or al-Bayt al-Muqaddas is the centre of the centre of Barakah (2019: 16-17). In other words, al-Aqsa Mosque is the core or nucleus of the world. El-Awaisi uses several examples to explain why there are circles around the centre or the heart. He refers to physics and claims that circles around al-Aqsa are similar to circles around an atom. Electrons revolve around the centre in line with their energy degree and the electromagnetic force will depend on the distance between the core and electrons (2019: 22-23). In this sense, the closer one gets to the centre, the more the ratio of the Barakah increases and vice versa (2016: 22-23). This explanation provides a helpful pattern for the high level of conflict in the Middle East and the nearly total absence of conflict in Western Europe or Canada on a systemic level. To be clear on the 
theoretical framework, one needs to further explain the circles. El-Awaisi states that there are three circles around the centre of the world:

- $\quad$ First Circle: Islamicjerusalem

- Second Circle: Egypt, Bilad al-Sham and Cyprus.

- $\quad$ Third Circle: Iraq, Turkey, Hijaz.

The reason why the word Islamicjerusalem is preferred instead of Jerusalem is another interesting point in Professor El-Awaisi's work. In his study, he refers to Muslim scholars and claims that the borders of Islamicjerusalem reach up to 40 Arab Miles $(85,04 \mathrm{~km})$ in every direction. In this sense, the author claims that the borders of Islamicjerusalem should not be reduced to al-Aqsa3 (El-Awaisi, 2019: 28). In addition to this, according to the Barakah Circles theory, whoever controls the first circle controls the second circle. And whoever rules the second circle, controls the third one and eventually, ruling the third circle will result in controlling the world. But this does not refer to an exclusivist understanding. The reason for such a claim is simple. If any conflicts do appear in Islamicjerusalem, as suggested by El-Awaisi, it will spread to the world (2016: 51-54). For instance, an article dated to 2003 argues that challenges in the Middle East affect Europe's security (Kemp, 2003: 176). The struggle between Arab states and Israeli provides a good example in support of this claim. The wars that took place near Islamicjerusalem and their effects reached Europe as well. This may be in terms of economic issues because of the financial chaos in relation to the oil embargo, as well as in relation to political issues, since the war almost severely damaged the relationship between US, Europe and Israel (Zakariah, 2012: 607).

Additionally, El-Awaisi frequently highlights the importance of a unity between Egypt and Syria in his book. According to his research, there is an organic tie between Egypt and Syria. A unity between these states will provide a powerful stance for the state that has the control over the region (2019: 30-33). Taking Egypt's and Syria's geopolitical positions into account, one might say that a unity in the region might form a powerful 'castle' in the 'Orient' as was the case during the time of the Ottoman Empire. Moreover, this might prevent colonialist policies that divide the region in favour of some states. Orientalism, according to Said, describes Western attitudes towards the East. Additionally, Orientalist researches have been the 'systematic learning, discovery and practice' of the West to move upon the East (1979: 73). One might even argue that Orientalist studies caused the separation of Egypt and Syria. However, it seems that there is no description on the nature of the alliance in El-Awaisi's theory. Describing its nature might allow experts and scholars to develop a more explicit solution for instability in the region. That said, the theory's inclusivist nucleus does provide some clues for stability in the region.

In summary, the geopolitical proximity of states to al-Aqsa, and their relations (united/separated) according to this new approach, determines their fate in terms of stability or instability. The Barakah Circles theory suggests that a 
cooperation or an alliance between Egypt, the Levant or Old Syria and Cyprus is necessary for the conquest of Islamicjerusalem. However, the conquest of Islamicjerusalem should not then be used to suggest or propose to regional actors or states to start a war (El-Awaisi, 2019: 32-33). If this was the case, it would be plausible to claim that this approach is exclusivist. On the other hand, this theory proposes a unity in the region which means that it is an inclusivist approach in its essence. El-Awaisi argues that his theory does not mean any domination of a certain social group or ethnicity over another (2019: 59). In this sense, one might say that the proposal is a kind of harmony in the region. From this point of view, what is necessary for stability in the region might be a regional power that has historical ties with the region. That is the reason why this study focuses on the Ottoman Empire's status in the region. In sum, an inclusivist understanding of the Barakah Circles will be used to test its practicability through a historical and systemic context.

\section{OTTOMAN AS A STABILISER AND REASONS OF INSTABILITY}

The Ottoman Empire, starting from the $16^{\text {th }}$ century, established its presence and power in the Middle East. At first, there was relative stability. As a well-known fact, the Ottoman Empire survived and maintained its powerful position against European imperialism for almost six hundred years (Quataert, 2005: 84). From the theoretical perspective of this study, one might say that this stance was the result of having a united Egypt and Syria. However, along with its military power and governing structure, one might say that this was the result of its inclusivist policies. As Hathaway argues in her book, "The Ottomans tended to allow their non-Muslim subjects a fair degree of autonomy so long as they remained obedient and paid their taxes.". Additionally, non-Muslim groups and minorities had their own rights, such as living their own religion and/or belief under the protection of the state (2008: 34).

In other words, the Ottomans did not implement segregationist policies during their period of ruling, both in terms of religion and nationality. Throughout its history, there were different ethnic and religious groups settled in the Ottoman Empire and their relationship with the state was harmonious and collusive until nationalism started to meddle with this cooperative relationship. The cooperative nature of the Ottoman ruling system can also be seen in its way of recruiting governors. The Ottoman Empire had a policy called Devşirme 4 until 1622 and the people who educated with the Devşirme policy were from a wide range of ethnicities (Quataert, 2005: 99). Another example is the Polish village in Istanbul. Polish people who were fleeing from Russian occupation in the $19^{\text {th }}$ century took refuge in the Ottoman Empire and given a land to live: this was termed the Polonezköy or Polish Village in English (Consulate General of the Republic of Poland in Istanbul).

Contemporary troubled relations between Palestine and Israel, in particular, and instability in the Middle East, in general, can to some extent be 
considered as the legacy of the decline of the Ottoman Empire (Quataert, 2005: 174). It is plausible to claim that nationalism is the virus that caused the deceased interactions of the region states. In a way, as Eagleton argues, nationalism is a form of alienation (1990: 23). Or more accurately, regarding the situation in the Middle East, the establishment of nation-states in the region is one of the main reasons for instability. Because establishing nation-states in the region means dividing Arabs and therefore nation-states created an exclusivist logic in the minds of region states' decision-makers. Additionally, as an extreme form of nationalism, racism will assist the colonial policies of Western powers (El-Awaisi, 2019: 60).

Moreover, in the modern world, nation-states are founded on their own values, norms, peoples and wars. Almost every nation-state in the Middle East is artificial since the boundaries were determined by Imperial powers after the World War I. The demarcation was 'reflecting delimitations' of these powers to each other (Abi-Aad \& Grenon, 1997: 91). Thus, artificial borders as a result of these colonial demarcation policies as set by the colonisers are the roots of instability in the region (Green \& Luehrmann, 2011: 51). It is noteworthy that the real rise of Europe had begun with the fall of the Berlin Wall or one might say that it began with the end of artificiality in Europe. Yet, nation-states are not the only form of the exclusionary nature of the Middle East. In the contemporary situation, "Islamism blends with, nationalism in the context of resistance against nonMuslim foreign domination and/or occupation." (Ayoob, 2008: 112). On the other hand, Russia too carries out colonial policies even though it is still contested to refer it as a Western power. For instance, one of Russia's plans regarding Syria is to restore its state apparatus in line with Russia's doctrines (Abu Shakra, 2020). In one study, it was argued that the turmoil in the region is attributed to the undermining of the democratisation process. While the author's solution is not in the same vein as this study, the reason for turmoil or instability is presented as the presence of foreign powers (Dalacoura, 2018: 44). In other words, foreign presence or domination in the region is another reason for instability.

After World War I, the Empire was constrained because of its defeat in the war to accept the consequences of the Sykes-Picot Agreement between France and Britain. In compliance with this agreement, the region that is known as Syria today was given to France; Palestine was given to Britain (Mather, 2014: 471). What is interesting in this share is that France was interested in Syria and Britain was interested in Palestine. The great powers of their era shared the region, but for what purpose? From the common point of view, one might say that they shared the region because it possessed raw materials. Moreover, the continuation of instability in the region is the result of the power play of USA and Russia over oil. However, even though this is true to some extent, this is not a comprehensive interpretation. The oil centric interpretation only focuses on the raw materials but ignores the geopolitical motivation behind colonialism.

During its time of rule, the Ottoman administrative structure was based on decentralisation. Every conquered area was bounded by law (kanunnâme) to the 
centre. However, every province -especially Egypt - had some privileges and were free to order their internal affairs. The law that was given to Egypt in 1525 by the Grand Vizier Ibrahim Pasha included certain privileges for Egyptian governors, such as being the vault for regional taxes that will be sent to Istanbul (Hathaway, 2008: 48-51). Eventually, an Egyptian governor used these privileges for his own benefit and became a source of threat for Istanbul. After the threat caused by Muhammad Ali Pasha of Egypt with his attempt to declare his independence in 1838, the Ottoman Empire was saved by the coalition of Britain, Austria, Prussia and Russia (Quataert, 2005: 58). What seems to be interesting is that all these powers were implementing different policies to overthrow the Ottoman rule out of Anatolia and the Middle East. It must then be asked why they endeavoured to assist the Ottoman Empire. From a geopolitical perspective, the answer is simple. As Quataert argues, "Western powers were unwilling to permit the emergence of a dynamic and powerful Egyptian state that threatened the international balance of power" (2005: 58). In this sense, Western colonial superpowers were, at that time, willing to support a dying empire instead of a rising one.

While the West and Russia were planning to disintegrate the state, the Ottoman Empire was saved by them. From the Barakah Circles theory's perspective, what is interesting is that the Ottoman Empire faced a threat of what seemed to be total annihilation by a united Egypt and Syria. El-Awaisi frequently highlights the importance of a unity between Egypt and Syria in his theoretical perspective as constituting a powerful stance in the international sphere. For instance, the Ottomans seized control of Old Syria with its victory over Mamluk Sultanate after the Battle of Marj Dabiq in 1516. Right after the Marj Dabiq victory, the Ottomans marched to Egypt and overthrew the Mamluks in 1517 after the Battle of Ridaniya. According to El-Awaisi, Selim's attempt is evidence for the organic tie between Old Syria and Egypt (2019, 30-31). From this perspective, a power that is not able to unite and control these two areas will lose its dominant role or ruling power as occurred in the time of the Ottomans.

Despite their efforts, the Ottoman Empire could not prevent the inevitable end. The end of World War I brought nothing but the beginning of the ultimate collapse of Ottoman Empire, which had begun decades before the war. Previously emerging conflicts in the region reached its peak during this process (Mather, 2014: 472). In this sense, one might say that the weaker a regional power is, the more observable is the instability in the region. For instance, during the decline of the Ottoman Empire, the Jewish settlement in Jerusalem dramatically expanded (Wallach, 2016: 278). And the longer the absence of a regional power continues to be the current pattern, the more Israeli occupation expands. This is in addition to terrorist organisations like ISIS and YPG that are more likely to survive in the region because of the lack of an established regional power to bring stability.

According to Mather, the roots of the conflict in the region go back to the new states which were established by the two international powers that signed the Sykes-Picot Agreement in 1916. She argues that these new nation-states were 
'suited to their interests' in disintegrating the Ottoman Empire (2014: 472). From this point of view, one might say that it was foreigners to the region that had established the conflict instead of independent states. And to some extent these states that were established substituted for the stability in the region. Yet this is not to suggest that the nation-state is a problem for all regions of the world. One can only consider Turkey, Egypt, Iran and Israel as true nation-states in the region (Tira, 2016: 57). Residents in most of the countries in the region, such as Saudi Arabia, United Arab Emirates, Syria, Egypt, Iraq, Qatar and Lebanon are, in fact, Arab states. So, there are at least seven different Arab ethnicity-oriented nationstates in the Arab world. Even though it might be argued that there are different Turkic nation-states, the situation in the Arab world is slightly different. For instance, Turkey has clear-cut boundaries and its historical depth seems more explicit compared to that of the Arab world's (Baram, 1990: 427). The point here is that, there are no genuine nation-states, rather, there are political entities that are ruled by a small group or a family. However, being a 'nation-state' benefits those ruling classes, as well as the colonial powers in the Middle East.

This bring us to the political instability in the region. Ayoob argues that security issues are rooted within the society of third world states (1983: 43). Therefore, insecurity operates at the regime level. While it might seem harmless to the rest of the world, there is a crucial issue that needs to be understood. This kind of insecurity might cause an outside intervention, as in the Syrian case. (Stivachtis, 2019: 11). Additionally, any conflict in the region might affect the world as well. In this sense, the character of region states along with the nation-state issue is a crucial factor for the instability that they acquired after the decline of Ottoman Empire.

From this point of view, one might claim that the conflict in the region is the result of continuing colonial policies (Mather, 2014: 472). To understand Britain's interest over Palestine, El-Awaisi's research provides a helpful guideline. According to El-Awaisi's research, Britain had been trying to establish a buffer zone in Palestine to separate the Arab World from Africa to make it easier to implement Britain's colonial policies (2019: 36). Furthermore, some claim that the establishment of the state of Israel was "symbolic of the triumph of Western imperialism over the entire Arab world." (Green \& Luehrmann, 2011: 52). As was already mentioned, establishing nation-states in the region was for the benefit of Britain or superpowers in general. After the superpower status of Britain declined with the end of World War II, the USA supplanted Britain's position and has maintained its role as the major actor in the Middle East ever since. US humanitarian intervention policy to intervene the region - as in the case of Iraq's invasion - is similar to Britain's effort to promote nation-states in the region in terms of their resemblance in sustaining 'colonial' policies.

Mather's analysis highlights that humanitarian interventions are a means to maintain US geopolitical hegemony (2014: 454). For a comprehensive understanding, one needs to explain this argument. Globalisation has been used 
to cover up the intentions. Evidence of this hypocrisy can be seen in Western support for democracy as an extension of globalisation. The US did not accept the victory of Hamas in elections but "stopped short of calling the downfall of Mohamed Morsi a coup" (Roberts, 2013). No less importantly, el-Sisi's actions have been supported in the name of "democracy restoration" by great powers. From this point of view, one might claim that the West only supports democracy regarding its interests (Green \& Luehrmann, 2011: 310). Therefore, globalisation might be considered as the new way or another name for protecting the dominant position of the West over the 'Third World', or more specifically, over the Middle East (Ehteshami, 2007: 23).

Another example of Western hypocrisy is the so-called 'deal of the century'. On 29 $9^{\text {th }}$ January 2020, US President and Prime Minister of Israel Netanyahu signed a deal - even though there were not any Palestinian representatives during the planning and signing - which recognises Jerusalem as Israel's capital and strengthens Israel's position in the world affairs. After Trump presented the plan, Netanyahu stated that US President 'Trump is the greatest friend that Israel has had in the White House' (BBC, 2020). In light of the aforementioned examples, the solution is not the continuation of the rule of several foreign states, but rather it might be a regional power that is familiar with the region states and has historical ties with the region in terms of culture, etc.

In this sense, as El-Awaisi suggests, an alliance in the region should be inclusivist to achieve stability (2016: 51-54). When Britain left the area, six different wars broke out among Arab states and Israel. As the strongest member of the Arab side, Egypt was crucial. Egypt's defeat in the war resulted in losing its 'hegemony' in the region (Hinnebusch, 2017: 608). According to El-Awaisi, the Fifth Crusader targeted Egypt because of their strategy to reach inner parts of the Middle East. Additionally, pointing to Salahuddin al-Ayyubi's strategy to maintain his power, El-Awaisi claims that Egypt is a crucial state in region (2019: 32-33). The decline of Egypt and - related to its decline - the results of Arab-Israel wars, are another supporting historical event for the Barakah Circles theory.

Even though a unity among Arab states was a failed attempt, with numerous reasons for this outcome, this example presents an important element for stability in the Middle East. When there are no superpowers in the region, the chance for an alliance is more likely, as in the case of the Arab alliance against Israel. On the other hand, hosting US, Russia and several powers on the ground, along with the division between regional actors, means that an alliance in the region seems unlikely to occur. For instance, Syria's vulnerability regarding the interventions caused the prolongation of instability in the region (Dalacoura, 2018: 37). In other words, interactions between regional states should be beyond nationalistic movements as the Ottoman Empire had implemented. It should be noted that an important reason why the Arab alliance against Israel failed even though Egypt and Syria were united might be the exclusivist nature of the alliance. As discussed before, stability in the Middle East requires an inclusivist attitude. 
However, the alliance was the result of an exclusivist policy that was affected by nationalism as its name implies.

\section{Is There a Solution for the Instability?}

As argued above, instability in the region is the result of Western colonial policies. Additionally, the presence of foreigners in the region prevents stability. As the assassination of Suleimani showed, US policies resulted in tension rather than stability (Parsi, 2020). Such behaviour caused states and individuals in the region to feel more insecure than before. This study argues that the solution is possible, but that a regional power that has historical ties with the region seems necessary. However, determining a suitable actor seems problematic.

As El-Awaisi's work proposes, there are four central powers in the region: Egypt, Syria, Iraq and Turkey. However, Egypt witnessed a coup, Iraq was invaded, and Syria has been the playground of many actors since 2011. Hence, Turkey seems the only power that might be able to take on this role (2019: 56-57). According to the Barakah Circles theory, Turkey is on the third circle and the central power in the region (El-Awaisi, 2019: 55-56). Therefore, it is plausible to assume that Turkey is key as the starting point for stability. If Turkey managed to spread stability from the outside in, a relative stability might occur. Another reason to present Turkey as the key actor for stability in the Middle East derives from its historical ties with the region. As Gopin argues, during a peace talk, the one who perceives himself/herself superior does not take others' ideas into account. According to the author, catastrophic consequences in communication derive from this type of relating (2002: 146-147). In this sense, what is necessary for instability is mutual understanding between actors that have historical ties.

Additionally, Turkey's foreign policy attitude towards the region exemplifies and supports the main argument of this study. Turkey has been implementing inclusivist policies towards the Middle East in recent years. Hosting refugees, eliminating exclusivist actors and attempting to balance the tension in the region exemplifies the inclusivist policies. Because of its inclusivist attitude, Turkey might become a regional power. However, this not to suggest an 'elder brother' role for Turkey to unite the region. In this sense, Turkey as a state which has historical ties with the region and an inclusivist actor seems up to the task. As for Iran, its exclusivist policies - regarding sectarian issues that require further research - cannot bring and maintain stability to the region. However, the other side of the coin presents another reality that should not be neglected. As in the case of former Soviet states, a regional power may not be 'welcomed' by its neighbours in all circumstances (Parlar Dal, 2016: 1247). This is especially in the case of the Middle East in relation to England's effort to restore Arabs trust for Europeans rather than countries that have historical ties with region states after the Arab-Israeli wars (Zakariah, 2012: 608). Additionally, there is the Western hegemonic presence in the region. Recent events in the region showed that "the Middle East will have to get used to the idea of sharing living space with a 
meddling American superpower that refuses to go home." (Bridge, 2020). Even though that superiority seems to be shifting towards the Russian Federation, the USA is still the playmaker regarding the hegemony issue. When considering the decades-long colonial policies, it does not seem likely for the West to leave the area even though the main precipice preventing the stability in the region are the foreigners.

In line with above mentioned issue, a recent example shows that Turkey's position as a regional power might not be welcomed by Middle East states. There are, of course, limits for Turkey's influence in the region. Some researches highlight that Turkey's engagement with the region might 'jeopardize its attractiveness as a role model' in the region (Öniş, 2014: 216). On the other side of the coin, there is another reality for Turkey's role as the stabiliser in the region. Recently, Arab League Secretary General Ahmed Aboul Gheit purported to view Turkey's Operation Peace Spring as 'an invasion of an Arab land' (Reuters, 2019). Yet there are no signs of any official Arab League condemnation of U.S or Russian interference in Syria (Telci, 2019). Such practices of double standards when it comes to Turkey is a sign that Arabs will not welcome Turkey's position in short term. As mentioned above, the Barakah Circles theory suggests that a unity of Egypt and Syria is necessary for stability and power in the region. However, the only state that is up to the task of bringing stability to the region seems to have adversaries. The maritime agreement between Turkey and Libya was condemned by Egypt (Egypt Today, 2019). Also, recent Russian policies towards Turkey is a great obstacle in Turkey's way. From this point of view, stability in the region by bringing Egypt and Syria under a regional power's support seems unlikely in the short term because of regional disputes and foreign interferences.

In light of the above discussion, not all inclusivist approaches will be the solution. Ukraine, for instance, has been considered as part of the Russian states for almost 200 years (Kubicek, 2008: 45-52). However, their approach is based on controlling and 'colonising' the region. Another example is England's policies during the Arab-Israel wars. Even though England was the most willing state to bring peace among the region states, the main reason was to preserve London's oil interests (Zakariah, 2012: 600). In this sense, England's strategy was to sustain its colonial policies. Thus, bringing stability to the region by a power that implements an inclusivist policy should take place in a realistic sense and carried out in a transparent nature; it might take some time to achieve this because of the feeling of insecurity among region states. Furthermore, the division in the minds of decision-makers and citizens of region states is more visible and deeper than is seen on the maps. Therefore, a regional actor that desires to be a stabiliser in the region should first try to establish a platform that serves as a reminder that the states in the region are not based on different nations.

\section{CONCLUSION}

As the discussion above presents, there are three major reasons for the instability; 
- Continuation of the presence and the colonial policies of Western powers in the region.

- Lack of inclusivist policies as a result of nationalism and the establishment of nation-states. Or alternatively, due to artificiality in the region along with the security understandings.

- Lack of a dominant regional power that has historical ties with the region.

The Ottoman Empire sustained its position against Western colonial policies and suffered greatly in trying to maintain stability over its lands. The Empire aimed to implement a fair ruling policy over its subjects. As a power that implemented inclusivist policies, the Empire managed to maintain stability in the Middle East for centuries. However, after the decline of its power, instability began to be the new feature of the region. As history suggests, the more visible the decline of a power in the region, the more the ratio of instability increases, as in the time of Ottomans or the time of the British mandate. Even today, since there is more than one power that desires to establish their presence in the region, such as USA and Russia, establishing the stability or even drawing a draft manual on how to do this, is not likely to occur in the short term. Unless the artificiality of the Middle East by nation-states, which was the result of colonial powers' policies, is altered, stability will not occur in the region in the long term either. Along with the nation-state issue, the security understanding of region states causes the instability by attracting opportunistic aggressors in the region (Stivachtis, 2019: 11).

From the perspective of the Barakah Circles theory, what is needed for stability in the Middle East is an inclusivist power that is able to unite Egypt and Syria in particular. As argued in the text, the nature of an alliance between Egypt and Syria needs to be described in line with the nature of the Middle East states. Any solid and realistic description might be helpful for future studies that focus on instability in the Middle East. In addition to the alliance discussion, an inclusivist approach requires a transparent agenda to prevent any skeptical perception of region states. However, stability needs to be established on the state level as well. Egypt needs to be convinced to act willingly to cooperate with region states in favor of stability and Syria's state apparatus needs to be constructed. The only way of achieving this purpose seems to be a powerful regional state that acts in an inclusivist manner.

Moreover, an inclusivist regional power might unite and reconstruct these two separated states for the purpose of forming a stance against colonial policies. In this sense, as discussed above, Turkey seems to be the only power that might establish stability. However, as mentioned several times in the article, a regional power needs to implement an inclusivist approach and needs to be recognised by other regional actors. Otherwise, nothing will change in the region since the very reason behind the instability is the exclusivist policies of colonial and regional powers. As for the final aim of this study, the inclusivist nucleus of the Barakah Circles theory seems to provide the necessary steps for bringing stability in the 
region. This study is an attempt to provide a solution. However, researchers or strategists should focus on recent world politics and try to provide guidance for more concrete steps to bring and establish stability in the region since a theory can only draw a pattern and cannot be the cement for every crack in the regional structure.

\section{BIBLIOGRAPHY}

Abi-Aad, N. \& Grenon, M. (1997), Instability and Conflict in the Middle East: People, Petroleum and Security Threats, London: Macmillan Press.

Abu Shakra, E. (2020), "The Future of Syria: We Talk While Others Think", Asharq al-Awsat, February 17, available at: https://aawsat.com/english/home/article/2135431/eyad-abushakra/future-syria-we-talk-while-others-think.

Ayoob, M. (1983), "Security in the Third World: The Worm About to Turn", International Affairs, 60:1, pp. 41-51.

Ayoob, M. (2008), The Many Faces of Political Islam: Religion and Politics in the Muslim World, Ann Arbor: University of Michigan Press.

Baram, A. (1990), "Territorial Nationalism in the Middle East", Middle Eastern Studies, 26:4, pp. 425-448.

Bridge, R. (2020), "Now Iran \& Iraq Both Want the US to leave the Middle East, but it Never will", RT, January 9, available at: https://www.rt.com/op-ed/477842-us-leave-middle-east-iran-iraq/.

Dalacoura, K. (2008), “Democratic Transitions in the Levant: Prospects for Restoring a Regional Order", Uluslararası ilişkiler, 15:60, pp. 31-44.

Eagleton, T. (1990), "Nationalism: Irony and Commitment", In Nationalism, Colonialism and Literature, edited by: Terry Eagleton, Fredric Jameson \& Edward W. Said, 23-39, Minneapolis: Minnesota University Press.

El-Awaisi, Abd al-Fattah. (2016), Beytülmakdis Bereket Daireleri Teorisi: Yeni Bir Jeopolitik Teori, translated by: Emine Nur Kafalı, Kübra Arslan \& Kübra Türk, İstanbul: Pelikan Basım.

El-Awaisi, Abd al-Fattah. (2019), Beytülmakdis ve Geleceğimizin İnşası: Uluslararası Iliş̧kilerde Yeni Bir Tasavvura Doğru, translated by: Emine Nur Kafalı, Kübra Arslan \& Kübra Türk, İstanbul: Beytülmakdis Çalışmaları Vakfı-iHH.

El-Awaisi, Khalid. (2007), Mapping Islamicjerusalem: A Rediscovery of Geographical Boundaries, Dundee: Al-Maktoum Institute Academic Press.

Ehteshami, A. (2007), Globalization and Geopolitics in the Middle East: Old Games, New Rule, Oxon: Routledge.

Ergul Jorgensen, A. A. (2019), "The Middle East: Between Myth and Reality", Global Affairs, 5:1, pp. 81-88.

Gopin, M. (2002), Holy War, Holy Peace: How Religion Bring Peace to the Middle East, New York: Oxford University Press.

Green, D. \& Luehrmann, L. (2011), Comparative Politics of the Third World: Linking Concepts and Cases [Third Edition], London: Lynne Rienner Publishers.

Hathaway, J. The Arab Lands Under Ottoman Rule, 1516-1800. Oxon: Pearson, 2008.

Hinnebusch, R. (2017), "Revisiting the 1967 Arab-Israeli War and its Consequences for the Regional System", British Journal of Middle Eastern Studies, 44:4, pp. 593-609.

Kemp, G. (2003), “Europe's Middle East Challenges”, The Washington Quarterly, 27:1, pp. 163-177. Kubicek, P. (2008), The History of Ukraine, Westport: Greenwood Press.

Mather, Y. (2014), "The Fall of the Ottoman Empire and Current Conflict in the Middle East", Critique: Journal of Socialist Theory, 42:3, pp. 471-485.

Öniş, Z. (2014), "Turkey and the Arab Revolutions: Boundaries of Regional Power Influence in Turbulent Middle East", Mediterranean Politics, 19:2, pp. 203-219. 
Parsi, T. (2020), "The Middle East is More Stable When the United States Stays Away", Foreign Policy, January 6, available at: https:/foreignpolicy.com/2020/01/06/the-middle-east-is-morestable-when-the-united-states-stays-awayl.

Richards, A. (1995), "Economic Roots of Instability in the Middle East", Middle East Policy, 4:1, pp. 175-187.

Roberts, D. (2013), “US bind over Egypt after supporting Morsi but Encouraging Protesters", The Guardian, July 3, available at: https://www.theguardian.com/world/2013/jul/o3/egypt-obama-usmohamed-morsi-crisis.

Said, E. W. (1979), Orientalism, New York: Vintage Books.

Stewart, D. J. (2009), The Middle East Today: Political, Geographical and Cultural Perspectives, London: Routledge.

Stivachtis, Y. (2019), "Political (In)Security in the Middle East", E-International Relations, April 15, available at: https://www.e-ir.info/2019/04/15/political-insecurity-in-the-middle-east.

Telci, i. N. (2019), "Opposition to Turkey Reflects Arab League's Hypocrisy", Anadolu Ajansı, October 21, available at: https://www.aa.com.tr/en/analysis/opposition-to-turkey-reflects-arableague-s-hypocrisy/1621094.

Tira, R. (2016), "The Future Middle East Strategic Balance: Conventional and Unconventional Sources of Instability", Études de L'Ifri Proliferation Papers, 1:62, pp. 1-62.

Quataert, D. (2005), The Ottoman Empire 1700-1922, New York: Cambridge University Press.

Wallach, Y. (2016), "Rethinking the Yishuv: Late-Ottoman Palestine's Jewish Communities Revisited", Journal of Modern Jewish Studies, 16:2, pp. 275-296.

Zakariah, M. H. (2012), "Oil, War and European Initiatives for Peace in the Middle East 1973-74: British Attitude and Perspective", Middle Eastern Studies, 48:4, pp. 589-611.

"A Polish Village in Istanbul", Consulate General of the Republic of Poland in Istanbul, available at: https://stambul.msz.gov.pl/en/polish_community_in_turkey/poland_and_turkey_two_countries in_one_mirror/a_polish_village in istanbul.

"Egypt Condemns Signing of MoUs between Turkey, Sarraj on Maritime Jurisdictions", Egypt Today, November 29, 2019, available at: https://www.egypttoday.com/Article/2/78243/Egyptcondemns-signing-of-MoUs-between-Turkey-Sarraj-on-maritime.

"Netanyahu: Trump Middle East Peace Plan 'Deal of the Century", BBC, January 28, 2020, available at: https://www.bbc.com/news/av/world-middle-east-51289277/netanyahu-trumpmiddle-east-peace-plan-deal-of-the-century.

"Peace and Security", European Commission, December 12, 2019, available at: https://ec.europa.eu/europeaid/sectors/human-rights-and-governance/peace-and-security_en.

“Turkey's Syria Offensive an 'Invasion': Arab League Secretary General”, Reuters, October 12, 2019, available at: https://www.reuters.com/article/us-arableague-turkey-syria/turkeys-syriaoffensive-an-invasion-arab-league-secretary-general-idUSKBN1WRoC9

\section{ENDNOTES}

1 'Middle East' is a simplifying concept to refer many countries from Africa to Arab World. However, the concept in this study refers to Arab World.

2 It should be noted that, this study does not ignore the non-state organisations and terrorist groups in the region. However, from the geopolitical perspective of this study, only the states in the region will be considered as the main actors.

3 For a detailed information on the boundaries of Islamicjerusalem, See: Khalid El-Awaisi, Mapping Islamicjerusalem: A Rediscovery of Geographical Boundaries, Al-Maktoum Institute Academic Press, Dundee, 2007.

4 Devşirme was an Ottoman policy for taking children from the conquered lands and educating them. The children were canalised regarding their abilities to have a position in Ottoman ruling class or military system. 